\title{
PENGARUH METODE COOPERATIVE SCRIFT DAN PERAN ORANG TUA TERHADAP PRESTASI BELAJAR BAHASA INDONESIA
}

\author{
Sigit Widiyarto \\ Universitas Indraprasta PGRI Jakarta
}

\begin{abstract}
Learning methods in the schools can determine the success students. But Mastery learning method is still less optimal. One of method to increase student activity is cooperatif scrift. This research used experimental method. The research findings: There is the effect of the method cooperatif scrift to achievement learn Indonesian. By using scrift Coopertif method can improve student achievement, so that better and proper administration of these methods will increase student learning outcomes. There is the influence of the role of parents to the student achievement Indonesian. The role of parents can improve student achievement. The role of parents is very important to support the child in improving learning achievement in school. There is the influence of cooperatif scrift methods and the role of parents simultaneously to achievement learn Indonesian. Provision of appropriate methods target will create an optimal learning process. The role of parents both at home and at school can support better result.
\end{abstract}

Keywords: cooperative scrift method, Role of Parents and The result of Bahasa Learning

\begin{abstract}
Abstrak
Metode pembelajaran di sekolah sangat menentukan keberhasilan belajar siswa.Namun Penguasaan metode masih kurang optimal. Salah satu metode yang meningkatkan keaktifan siswa untuk adalah Cooperatif Scrift. Penelitian ini memakai metode eksperiment. Hasil peneltian : Terdapat pengaruh pemberian metode Cooperatif Scrift terhadap prestasi belajar Bahasa Indonesia. Pemberian metode Coopertif Scrift dapat meningkatkan prestasi belajar siswa,sehingga makin baik dan tepat pemberian metode ini hasil belajar siswa akan meningkat. Terdapat pengaruh peran orang tua terhadap prestasi belajar Bahasa Indonesia. Peran orang terdapat meningkatkan prestasi belajar siswa. Peran orang tua sangat penting untuk mendukung anak dalam meningkatkan prestasi belajar di sekolah. Terdapat pengaruh pemberian metode Cooperatif Scrift dan peran orang tua secara simultan terhadap prestasi belajar Bahasa Indonesia. Pemberian metode yang tepat sasaran akan menciptakan proses belajar mengajar yang optimal. Peran orang tua baik di rumah maupun di sekolah dapat mendukung hasil belajar yang lebih baik.
\end{abstract}


Sigit Widiyarto : Pengaruh Metode Cooperative Scrift dan Peran Orang Tua Terhadap Prestasi Belajar Bahasa Indonesia

Kata kunci : metode Cooperative Scrift, peran orang tua dan hasil belajar BahasaIndonesia.

\section{PENDAHULUAN}

Pendidikan merupakan modal dasar untuk membangun Sumber Daya Manusia yang unggul. Pendidikan bukan hanya didapat dari lembaga formal yang disebut sekolah. Sekolah dikelola oleh pemerintah maupun swasta. Pendidikan berasal dari sektor formal dan informal. Semua sektor ikut andil dalam kemajuan pendidikan bangsa Indonesia. Kemajuan pendidikan tergantung peran pemerintah,keluarga dan masyarakat. Kemajuan pendidikan juga tergantung ,bagaimana sekolah melaksanakan manajemen sesuai dengan peran dan fungsinya. Sekolah juga mempunyai kegiatan atau program,sarana dan prasarana serta seluruh komponen penunjang. Salah satu komponen penunjang adalah pengembangan pembelajaran. Sebagai dunia yang dinamis dan terus berubah, pembelajaran semakin menyempurnakan diri sesuai dengan kondisi dan situasi yang ada saat ini. Pembelajaran semakin mengarah pada era kemandirian belajar, didukung dengan sarana telekomunikasi yang semakin baik akan lebih mendekatkan ruang, menghemat waktu, proses pembelajaran semakin fleksibel bagi semua orang. Belajar semakin mudah. Sedangkan belajar adalah suatu proses yang menyebabkan terjadinya suatu pembaharuan dalam tingkah laku, berhasil atau tidaknya belajar itu tergantung kepada beberapa faktor yang dibedakan menjadi dua faktor. Faktor tersebut antara lain, faktor internal dan eksternal. Faktor internal meliputi intelegensi, motivasi, kedisiplinan,kebiasaan, kecemasan, minat, dan sebagainya. Sedangkan faktor eksternal meliputi lingkungan keluarga,peran orang tua, lingkungan sekolah, lingkungan masyarakat, keadaan sosial ekonomi, dan sebagainya (Ahmadi, 2004: 138).Memenuhi tuntutan perkembangan jaman yang semakin maju, aspek pendidikan diharuskan membimbing dan mengarahkan peserta didik untuk 
menjadi lebih aktif dan kreatif. Keaktifan siswa hendaklah melibatkan siswa itu sendiri agar secara langsung belajar dan menemukan sebuah jawaban. Seringnya rasa malu siswa yang muncul untuk berkomunikasi membuat kondisi kelas tidak aktif. Hal seperti ini menyebabkan rendahnya prestasi siswa. Guru hendaknya memancing keaktifan siswa melalui model-model pembelajaran yang sesuai. Keberhasilan pencapaian tujuan pendidikan terutama ditentukan oleh proses belajar mengajar yang dialami siswa. Siswa dalam belajar diharapkan mampu mengalami perubahan baik dalam aspek kognitif, afektif, dan psikomotorik. Sikap-sikap yang harus diambil guru dalam proses pembelajaran hendaknya sesuai dan mampu membangkitkan kedisiplinan belajar siswa. Dengan meningkatkan daya ingat siswa pada materi yang telah di peroleh sebelumnya, dapat pula mempermudah meningkatkan kreativitas siswa karena kreativitas siswa merupakan kemampuan membuat kombinasi baru berdasarkan data dan informasi yang sudah ada. Meskipun guru sudah memancing keaktifan siswa di kelas,namun masih memerlukan metode yang tepat dipakai didalam kelas. Salah satu metode yang dikenal adalah Cooperative script. Cooperatif scrift adalah model pembelajaran dimana siswa bekerja berpasangan dan mengikhtisarkan bagian-bagian dari materi yang dipelajari. Cooperative berasal dari kata Cooperate yang artinya bekerja sama, bantuanmembantu, gotong royong. Sedangkan kata dari Cooperation yang memiliki arti kerja sama, koperasi persekutuan. Script ini berasal dari kata Script yang memiliki arti uang kertas darurat, surat saham sementara dan surat andil sementara. Jadi pengertian dari Cooperative cript adalah naskah tulisan tangan sementara. Jadi pengertian dari Cooperative adalah Strategi belajar dimana siswa belajar dalam kelompok kecil yang memiliki kemampuan yang berbeda. Metode Cooperative Script menurut Departemen Nasional yaitu dimana siswa bekerja berpasangan dan bergantian secara lisan mengikhtisarkan bagian-bagian 
Sigit Widiyarto : Pengaruh Metode Cooperative Scrift dan Peran Orang Tua Terhadap Prestasi Belajar Bahasa Indonesia

materi yang dipelajari. Jadi pengertian dari Metode Cooperative Script adalah Metode belajar dimana siswa bekerja berpasangan dan bergantian secara lisan.

Miftahul A'la (2011: 97), model pembelajaran Cooperative Script disebut juga Skrip kooperatif adalah metode belajar dimana siswa bekerja berpasangan dan secara lisan mengikhtisarkan bagian-bagian dari materi yang dipelajarinya dalam ruangan kelas. Cooperative Script merupakan model pembelajaran yang dapat meningkatkan daya ingat siswa (Slavin 1994:175). Hal tersebut sangat membantu siswa dalam mengembangkan serta mengaitkan fakta-fakta dan konsep-konsep yang pernah didapatkan dalam pemecahan masalah. Pembelajaran Cooperative Script merupakan salah satu bentuk atau model pembelajaran kooperatif. Model pembelajaran Cooperative Script dalam perkembangannya mengalami banyak adaptasi sehingga melahirkan beberapa pengertian dan bentuk yang sedikit berbeda antara yang satu dengan yang lainnya.

Riayanto (2009:280), Langkah-langkah untuk menerapkan model pembelajaran Coopertive script adalah sebagai berikut:

1. Guru membagi siswa untuk berpasangan.

2. Guru membagikan wacana/materi tiap siswa untuk dibaca dan membuat ringkasan.

3. Guru dan siswa menetapkan siapa yang pertama berperan sebagai pembicara dan siapa yang berperan.

4. Pembicara membacakan ringkasannya selengkap mungkin dengan memasukkan ide-ide pokok yang kurang lengkap.

5. Membantu mengingat/menghafal ide/ide pokok dengan menghubungkan materi sebelumnya atau materi lain.

6. Bertukar peran, semula berperan sebagai pembicara ditukar menjadi pendengar dan sebaliknya. 
7. Merumuskan kesimpulan bersama-sama siswa dan guru.

8. Penutup.

Sedangkan peran orang tua tidak bisa dipisahkan dari keberhasilan anak dalam proses belajar mengajar di sekolah. Menurut Baber (1953) dalam bukunya "Marriege and The family", membentuk keluarga biasa juga didasarkan hasrat berkumpul bersama secara kontinyu dengan orang yang dicintai. Pendidikan yang baik kepada anak -anak berarti telah memfungsikan keluarga sebagai tempat mendidik secara baik. Dampak dari peran orang tua tentunya dapat dirasakan oleh anak.Fungsi keluarga sebagai penerus kebudayaan dan pembentukan karakter akan memajukan pendidikan baik di rumah maupun di sekolah.

\section{METODE PENELITIAN}

Penelitian dilaksanakan pada siswa-siswi kelas X SMP Future Gate Jati Kramat Bekasi Jawa Barat. Adapun waktu pelaksanaan penelitian mulai bulan September sampai dengan Desember 2016. Penelitian ini menggunakan pendekatan kuantitatif. Menurut Sugiyono (2014:13)mendefinisikan metode penelitian kuantitatif dapat diartikan sebagai metode penelitian yang berlandaskan pada filsafat positivisme, digunakan untuk meneliti pada populasi atau sampel tertentu, pengumpulan data menggunakan instrumen penelitian, analisis data bersifat kuantitatif/statistik, dengan tujuan untuk menguji hipotesis yang telah ditetapkan. Perhitungan diperoleh melalui pengolahan dengan menggunakan teknik-teknik statistik pada program SPSS 22 for Windows. Analisa yang diperoleh dari penelitian ini akan dijelaskan secara deduktif untuk melihat hubungan setiap variabel penelitian dan menggunakan uji prasyarat serta uji hipotesis seluruh siswa dijadikan sampel penelitian. Teknik pengumpulan data menggunakan metode angket dan tes. Instrumen dalam 
Sigit Widiyarto : Pengaruh Metode Cooperative Scrift dan Peran Orang Tua Terhadap Prestasi Belajar Bahasa Indonesia

penelitian yaitu angket dan tes. Sampel adalah bagian dari populasi yang mewakili karakteristik yang ada pada populasi. Menurut Budiyono (2009: 121), sebagian populasi yang diamati disebut sampel atau contoh. Pengambilan sampel dilakukan dengan teknik stratified cluster random sampling.

\section{HASIL DAN PEMBAHASAN}

Metode yang digunakan dalam penelitian ini adalah metode eksperimen. Menurut Sugiyono (2011:72) Metode eksperimen adalah sebuah metode penelitian yang digunakan untuk mencari pengaruh perlakuan tertentu terhadap yang lain dalam kondisi terkendali. Metode ini merupakan satu-satunya metode penelitian yang menguji secara benar hipotesis yang menyangkut hubungan kausal (sebab akibat). Dalam penelitian eksperimen ini, peneliti melakukan pengukuran sebanyak satu kali yaitu sesudah perlakuan. Penelitian ini memakai uji prasyarat, normalitas dan homogenitas. Metode pengambilan data dengan menggunakan observasi,angket dan tes. Variabel peran orang tua para siswa diberikan angket,sedangkan prestasi belajar dengan menggunakan tes pilihan ganda (materi tentang negosiasi dan teks prosedur). Populasi terjangkau dalam penelitian ini adalah keseluruhan siswa SMA Future Gate, Jatikramat Bekasi tahun ajaran 2016-2017 dengan jumlah keseluruhan204siswa. Teknik pengambilan data yang pakai yaitu Random Sampling. Peneliti mengambil sampel dalam penelitian ini sebanyak 90 siswa kelas X SMA Future Gate Jatikramat, Bekasi. Peneliti membagi menjadi dua kelompok belajar siswa. Satu kelompok menjadi kelompok eksperimen yaitu diberikan metode pembelajaran Cooperatif Scrift. Kelompok kontrol adalah kelompok yang mempunyai peran orang tua yang rendah dan diberikan metode konvensional. 
Tabel 1. Desain Penelitian

\begin{tabular}{|c|c|c|}
\hline \multirow{2}{*}{$\begin{array}{c}\text { Peran } \\
\text { Orang tua }\end{array}$} & \multicolumn{2}{|c|}{ Metode Pembelajaran } \\
\cline { 2 - 3 } & Metode Kooperatif & Konvensional \\
\cline { 2 - 3 } & A1 & A2 \\
\hline Tinggi B1 & A1B1 & A2B1 \\
\hline Sedang B2 & A1B2 & A2B2 \\
\hline Rendah B3 & A1B3 & A2B3 \\
\hline
\end{tabular}

A1B1 : Model pemberian metode Kooperatif dan Peran orang tua yang tinggi.

A2B1 : Model pemberian metode konvensional dan peran orang tua yang tinggi.

A1B2 : Model pemberian metode Kooperatif dan Peran orang tua sedang.

A2B2 : Model Pemberian metode konvensional dan peran orang tua yang sedang.

A1B3 : Model pemberian metode Kooperatif dan Peran orang tua rendah.

A2B3 : Model Pemberian metode konvensional dan peran orang tua yang rendah.

Jumlah Sampel adalah 80 orang yang dibagi kedalam 6 kelas penelitian,masing-masing kelas penelitian berjumlah 15 orang.Berikut pembagian kelas penelitiannya, 15 siswa diberikan metode Cooperatif Scrift dan yang tinggi,15 siswa diberikan metode Kooperatif dan peran orang tua yang rendah,15 siswa diberikan metode konvensional dan peran orang tuayang tinggi, 15 siswa diberikan metode konvensional dan peran orang tua yang rendah. 15 siswa diberikan metode kooperatif dan peran orang tua rendah dan 15 siswa diberikan metode konvensional dan peran orang tua rendah. 
Sigit Widiyarto : Pengaruh Metode Cooperative Scrift dan Peran Orang Tua Terhadap Prestasi Belajar Bahasa Indonesia

Tabel 2. Ringkasan Hasil Uji Persyaratan Data

\begin{tabular}{|c|c|c|c|c|c|}
\hline \multirow{2}{*}{ No } & \multirow{2}{*}{ Variabel } & \multicolumn{2}{|c|}{ Uji Normalitas } & \multirow{2}{*}{$\begin{array}{c}\text { Uji } \\
\text { Homoge } \\
\text { nitas }\end{array}$} & \multirow[b]{2}{*}{ Kesimpulan } \\
\hline & & $\begin{array}{l}\text { Eksperi- } \\
\text { ment }\end{array}$ & Kontrol & & \\
\hline 1 & $\begin{array}{l}\text { Prestasi Belajar } \\
\text { Bahasa Indonesia }\end{array}$ & 0.078 & 0.163 & 0.153 & $\begin{array}{l}\text { Normal dan } \\
\text { Homogen }\end{array}$ \\
\hline 2 & Peran Orang Tua & 0.167 & 0.164 & 0.134 & $\begin{array}{l}\text { Normal dan } \\
\text { Homogen }\end{array}$ \\
\hline
\end{tabular}

Data uji persyaratan data menunjukan bahwa data prestasi belajar Sig.>0.05, yang menandakan data berdistribusi normal. Begitu pula dengan uji persyaratan homogen, Sig.> 0.05.

Tabel 3. Data Tabel

Between-Subjects Factors

\begin{tabular}{|ll|l|r|}
\hline & & Value Label & $\mathrm{N}$ \\
\hline metode_cooperatif & 1.00 & tinggi & 25 \\
& 2.00 & sedang & 26 \\
& 3.00 & rendah & 39 \\
Peran_orang_tua & 1.00 & tinggi & 22 \\
& 2.00 & sedang & 46 \\
& 3.00 & rendah & 22 \\
\hline
\end{tabular}

Dari tabel 3 nampak bahwa siswa yang mendapat nilai metode kooperatif tinggi,sedang dan rendah masing-masing sebanyak 25 siswa dan 26 siswa serta kategori rendah sebanyak 39 siswa. Sedangkan peran orang tua kategori tinggi sebanyak 22 siswa, sedang 46 siswa dan rendah sebanyak 22 siswa.

Pada kolom peran orang tua, siswa yang mendapat paling banyak katagori sedang,sebanyak 46 siswa. Baik metode Cooperatif dan peran orang tua jumlah keseluruhan sebanyak 80 siswa. 


\section{Tabel 4. Statistika Deskriptif}

Descriptive Statistics

Dependent Variable: nilai

\begin{tabular}{|ll|r|r|r|}
\hline metode_cooperatif & Peran_orang_tua & Mean & Std. Deviation & \multicolumn{1}{|c|}{ N } \\
\hline tinggi & tinggi & 78.2941 & 5.75288 & 17 \\
& sedang & 72.0000 & 6.02376 & 8 \\
& Total & 76.2800 & 6.45187 & 25 \\
\hline sedang & tinggi & 71.2000 & 7.46324 & 5 \\
& sedang & 55.9444 & 5.98500 & 18 \\
& rendah & 60.0000 & .00000 & 3 \\
& Total & 59.3462 & 8.35197 & 26 \\
\hline rendah & sedang & 50.1500 & 6.56366 & 20 \\
& rendah & 46.6316 & 6.43092 & 19 \\
& Total & 48.4359 & 6.65620 & 39 \\
\hline Total & tinggi & 76.6818 & 6.71449 & 22 \\
& sedang & 56.2174 & 9.90154 & 46 \\
& rendah & 48.4545 & 7.58273 & 22 \\
& Total & 59.3222 & 13.50724 & 90 \\
\hline
\end{tabular}

Tampak pada tabel 4, sebanyak 17 siswa yang mendapat metode cooperatif katagori tinggi ,dengan rata-rata sebesar 78.2941. Katagori sedang sebanyak 8 siswa dengan rata-rata 72.000 . 
Sigit Widiyarto : Pengaruh Metode Cooperative Scrift dan Peran Orang Tua Terhadap Prestasi Belajar Bahasa Indonesia

\section{Tabel 5. Tabel Anava 2}

Tests of Between-Subjects Effects

Dependent Variable: nilai

\begin{tabular}{|l|r|r|r|r|r|}
\hline Source & \multicolumn{1}{|c|}{$\begin{array}{c}\text { Type III Sum } \\
\text { of Squares }\end{array}$} & df & Mean Square & \multicolumn{1}{c|}{ F } & Sig. \\
\hline Corrected Model & $13059.411^{a}$ & 6 & 2176.568 & 56.841 & .000 \\
Intercept & 224497.345 & 1 & 224497.345 & 5862.758 & .000 \\
metode & 3065.544 & 2 & 1532.772 & 40.028 & .000 \\
peran_orang_tua_ & 892.613 & 2 & 446.307 & 11.655 & .000 \\
metode* peran_orang_tua_- & 268.400 & 2 & 134.200 & 3.505 & .035 \\
Error & 3178.245 & 83 & 38.292 & & \\
Total & 332959.000 & 90 & & & \\
Corrected Total & 16237.656 & 89 & & & \\
\hline
\end{tabular}

a. $\mathrm{R}$ Squared $=.804$ (Adjusted $\mathrm{R}$ Squared $=.790$ )

Pada kolom metode Sig. $=0.000$,dan $\alpha=0.05$, maka $\alpha>$ Sig. Dapat dikatakan H0A ditolak,dengan kata lain pemberian metode Cooperatif Skrift mempengaruhi prestasi belajar Bahasa Indonesia. Pemberian metode Cooperatif Scrift dapat meningkatkan prestasi belajar di sekolah.Pada kolom peran orang tua Sig. $=0.000$,dan $\alpha=0.05$, maka $\alpha>$ Sig. Dapat dikatakan H0A ditolak,dengan kata lain peran orang tua mempengaruhi prestasi belajar Bahasa Indonesia. Peran orang tua dapat membantu meningkatkan prestasi belajar siswa.

Pada kolom metode *peran orang tua Sig. $=0.035$, dan $\alpha=0.05$, maka $\alpha>$ Sig. Dapat dikatakan H0A ditolak,dengan kata lain pemberian metode Cooperatif Scrift dan peran orang tua dapat mempengaruhi prestasi belajar Bahasa Indonesia.

\section{KESIMPULAN}

Model pembelajaran Cooperative Script merupakan salahsatu cara atau strategi seorang guru dalam menyampaikan materi pelajaran, yang diawali dengan membagi siswa kedalam kelompok secil (satu kelompok terdiri dari dua 
orang/berpasangan), kemudian membagi materi ajar kepada siswa untuk dipelajari dan membuat ringkasan materi tersebut. Disini siswa dilatih untuk memberikan masukkan ide-ide atau gagasan baru kedalam materi ajar yang diberikan untuk mengomunikasikannya kepada teman sekelompoknya secara bergantian, siswa akan saling melengkapi satu sama lain. Dalam model pembelajaran ini mengikutsertakan semua siswa, sehingga semua siswa akan ikut berperan aktif dalam pembelajaran, dan diharapkan bisa membuat siswa bersemangat dalam belajar sehingga siswadapat memahami pelajaran dengan lebih mudah. Dalam cooperative scrift ini mengandung suatu unsur kerjasama dalam kelompok yang membuat siswa berperan aktif dalam pembelajaran, bukan guru. Guru bertindak sebagai fasilitator untuk mengarahkan dan motivator bagi siswa.

Berdasarkan hasil dan pembahasan yang telah diuraikan maka dapat disimpulkan:

1. Terdapat pengaruh pemberian metode Cooperatif Scrift terhadap prestasi belajar Bahasa Indonesia. Pemberian metode Cooperatif Scrift dapat meningkatkan prestasi belajar siswa ,sehingga makin baik dan tepat pemberian metode ini hasil belajar siswa akan meningkat.

2. Terdapat pengaruh peran orang tua terhadap prestasi belajar Bahasa Indonesia. Peran orang tua dapat meningkatkan prestasi belajar siswa. Peran orang tua sangat penting untuk mendukung anak dalam meningkatkan prestasi belajar di sekolah.

3. Terdapat pengaruh pemberian metode Cooperatif Scrift dan peran orang tua secara simultan terhadap prestasi belajar Bahasa Indonesia. Pemberian metode yang tepat sasaran akan menciptakan proses belajar mengajar yang optimal. Peran orang tua baik di rumah maupun di sekolah dapat mendukung hasil belajar yang lebih baik. 
Sigit Widiyarto : Pengaruh Metode Cooperative Scrift dan Peran Orang Tua Terhadap Prestasi Belajar Bahasa Indonesia

\section{DAFTAR PUSTAKA}

Isjoni.2009. Cooperative Learning. Bandung: Alfabeta.

Istarani.2011. 58 Model Pembelajaran Inovatif. Medan: Media Persada.

Miftahul A'la.2011. Quantum Teaching. Yogyakarta: Diva Press.

Riayanto Yatim.2009.Paradigma Baru Pembelajaran. Jakarta:Kencana Prenada Media Grup.

Slavin, R.E.1994. Educational Psychology: Theory and Practice. ThirdEdition.Massachusetts:Allyn and Bacon.

2008.Cooperative Learning Teori, Riset dan Praktik. Bandung: Nusa Media. 